\title{
Participatory variety selection of improved orange- fleshed sweet potato varieties at Gedeb district of Gedeo zone, Southern Ethiopia
}

\author{
Bililign Mekonnen \\ South Agricultural Research Institute, Hawassa Research Center, P. O. Box 1226, Hawassa, Ethiopia. \\ Email: bililign.m@gmail.com
}

Copyright (C) 2021 Mekonnen et al. This article remains permanently open access under the terms of the Creative Commons Attribution License 4.0, which permits unrestricted use, distribution, and reproduction in any medium, provided the original work is properly cited.

Received 9th May, 2021; Accepted 10th July, 2021

\begin{abstract}
Orange-fleshed sweet potato (OFSP) is a bio-fortified crop that is a rich source of beta-carotene (pro-vitamin A) which is necessary for combating the problems related to vitamin A deficiency (VAD). There is an increasing demand by farmers for production and consumption of improved OFSP varieties in the study areas. In order to respond to farmer requests, participatory variety selection trial was conducted with the objective of selecting superior OFSP varieties with farmer's preferred traits. The trial was conducted during 2019 and 2020 growing seasons across three sites in Gedeb district of Gedeo Zone. Six varieties, including one old OFSP variety as a check were tested in a mother trial using each site as a single replication. For a baby trial, one new and one old variety was given to more than 30 model farmers around each site. Data were collected on agronomic traits such as root yield, above ground biomass, harvest index and sweet potato virus disease from the mother trial and analysis of variance was conducted. The combined analysis showed the presence of significant differences $(p \leq 0.05)$ among tested genotypes for observed traits. The highest root yield was recorded for Dilla (23.11 t/ha), followed by Alamura (22.57 t/ha), Kabode (18.66 t/ha) and NASPOT-13 which produced the lowest root yield of $12.10 \mathrm{t} / \mathrm{ha}$ as compared to the others. Demonstrations of various sweet potato based foods were also made and 18 farmers (13 male and 5 female) were invited for variety assessment and selection based on the recipes. These farmers set sensorial attributes like flavor, taste, texture, and hardness of the cooked roots for taste-tests. Considering overall ranking of the six parameters (taste-tests) and agronomic traits such as root yield, above ground biomass, resistance to virus disease, varieties Dilla, Alamura, and Kabode were selected as the $1^{\text {st }}, 2^{\text {nd }}$ and $3^{\text {rd }}$ choices, respectively. Therefore, scaling up of these OFSP varieties should be done in the study area and areas with similar agroecologies in order to alleviate the problems related with VAD.
\end{abstract}

Keywords: Baby trial, mother trial, orange-fleshed sweet potato, participatory variety selection.

\section{INTRODUCTION}

Sweet potato [(Ipomoea batatas L. (Lam)] plays an immense role in human diet and it is mainly produced by smallholder farmers in Ethiopia. Especially, orangefleshed sweet potato (OFSP) is known to provide considerable health benefits for nutrition-endangered lowincome populations (Ginting 2013; Grüneberg et al., 2015; Alam et al., 2016; Bowser et al., 2017). The problem of vitamin A deficiency is of great public health concern of the poorer sections in nutritional victimization across the globe (Ritchie and Roser, 2017; FAO, 2018). Therefore, there is a great need for OFSP as a systematic diet of the consumers through food based approach for the resource poor farmers in densely populated sections in the era of extensive population growth and nutritional crisis (Rodrigues et al., 2016).

The increasing importance of this crop can be attributed 
to its potential to nutrition and food security in developing countries including Ethiopia (Mekonnen et al., 2021). According to previous reports by Tumwegamire et al. (2004), Tairo et al. (2004) and Van Jaarsveld et al. (2005) who indicated that high yielding OFSP with a small plot of just 500 square meters can meet the daily requirements of a family of five in resource poor farming communities. However, the farmers in the current study area grew the dominant old white fleshed variety (Awassa-83). This variety does not contain any beta carotene and another old variety (Kulfo), that has low dry matter content, which limited its acceptance by farmers remained very low (Gurmu et al., 2015). To solve this problem, a breeding program aimed at improving the root dry matter contents and beta carotene of orange-fleshed sweet potato varieties to replace an existing old OFSP was designed by Hawassa Agricultural Research Center in 2013 and has developed and officially released three improved orangefleshed sweet potato varieties in November 2019. However, these improved varieties have not been disseminated to farming communities in Gedeb district of Gedeo Zone. For this reason, once the potential varieties that meet the desires of farmers are developed through various methods, they need to be tested in the farmers' fields for their suitability to meet the preferences of farmers and to assess their acceptability by the farmers. Thus, participatory variety selection (PVS) is a more rapid and cost-effective approach in identifying farmers' preferred varieties than conventional method which ensures the access to good quality of planting materials of most preferred varieties to a large number of farmers within a short period of time (Ceccarelli et al., 2009; Tefera et al., 2013). Furthermore, in the study area farmers requested for the improved OFSP varieties to incorporate in their farming systems. Based on the request of famers, this study was designed to select superior OFSP varieties with farmer preferred traits in Gedeb district of Gedeo zone in Southern Ethiopia.

\section{MATERIALS AND METHODS}

\section{Description of the study area}

The participatory variety selection experiment was conducted during the main rainy seasons under rain-fed condition in 2019 (while the varieties were at their final testing stage for release) and in 2020 (after the varieties got released). The experiment was conducted at three sites. These sites were characterized by well drained loamy soil types at altitude ranges of between 1900 to 1996 meters above sea level. According to the Agriculture office of Gedeb district, the major crops grown in the areas are Maize, Coffee, Enset, Chat, Sweet potato and other root crops that are locally available. However, among the sweet potato varieties, almost all famers in the study area grow old white and orange fleshed sweet potatoes.

\section{Experimental materials and design}

Five orange-fleshed sweet potato varieties and one local (Kulfo) variety were used in this study, out of which three were recently released varieties with high dry matter, betacarotene and high root yield (Table 1). The experiment was conducted using the mother and baby design approach of Suwarno et al. (2002) using each site (farmer's field) as a replication.

\section{Experimental procedure}

The three sites (villages) were selected to conduct mother trial and a total of 30 farmers around each site were selected based on their consent and ability to provide land for the baby trial in collaboration with the development agents of the kebeles (villages). In the mother trial, all the six varieties were planted in each farmer's field as a single replication across the three sites (villages). Plot size was $10.8 \mathrm{~m}^{2}$ (contains six rows) with $3.6 \mathrm{~m}$ width and $3 \mathrm{~m}$ long for each variety was used in the mother trial. Planting materials of one new variety and one old variety as check were given to a total of thirty farmers who found around the three sites for a baby trial.

All plots received the recommended cultural practices uniformly and no fertilizer was applied (HwARC, 2015). Replanting was done to replace dead vines after one week of planting. Earthing up was done after fourth week of planting and all plots were kept weed free manually by farmers.

\section{Data collection}

Data were collected from mother trial on root yield, above ground biomass and sweet potato virus diseases. Besides, famers were invited to participate for variety evaluation at harvesting and after harvesting. At harvesting, variety evaluation was made based on agronomic performances of each variety while after harvesting taste-tests for organoleptic properties were conducted in collaboration with the food science research staff. The agronomic performance of the crop includes, diseases resistance/ tolerance, earliness to maturity, vine length and above ground biomass were recorded. The taste of all varieties was evaluated by preparing roasted and boiled roots, which constitute one of common ways of consumption of sweet potato by farmers in the study districts. Consequently, the tested varieties were evaluated for root yield and its component traits using analysis of variances across sites over seasons. 
Table 1. List of the orange fleshed sweet potato varieties used for the study.

\begin{tabular}{lllc}
\hline No & Name of variety & Root flesh color & Dry matter content (\%) \\
\hline 1 & Alamura & Deep orange & 31.8 \\
2 & Dilla & Deep orange & 32.4 \\
3 & Vita & Intermediate orange & 29.6 \\
4 & Kabode & Intermediate orange & 30.3 \\
5 & NASPOT-13 & Deep orange & 26.8 \\
6 & Kulfo & Pale orange & 22.5 \\
\hline
\end{tabular}

\section{Data analysis}

Collected data on root yield and its components were subjected to analysis of variance using SAS package (SAS 9.0). Data were checked for homogeneity of error variance for the two growing years using F-ma and it was not significant and then, the data was combined over years. Least significance differences (LSD) technique was employed to compare the treatments following the procedures of Gomez and Gomez (1984). Data on tastetests from farmers' perception was analyzed using SPSS software.

\section{RESULTS AND DISCUSSION}

\section{Performance of the varieties for root yield and yield- related traits across sites}

The combined analysis showed the presence of significant differences $(p \leq 0.05)$ among the tested genotypes for observed traits (Table 2). Three newly released varieties such as Alamura, Dilla and Kabode had higher root yield over the check variety Kulfo (Table 2). The roots yield of six tested varieties across three sites ranged from 12.10 to $23.11 \mathrm{t} / \mathrm{ha}$ with an overall mean of $18.02 \mathrm{t} / \mathrm{ha}$. In addition, differences in above ground biomass obtained from the varieties Dilla, Alamura and Kabode were significant with yields of $32.62,29.90$ and 25.88 tons per hectare as compared to the check variety Kulfo (17.15 t/ha), in that order across sites over seasons. This suggests that these three varieties could be the potential varieties to be used as a dual purpose crop (Low et al., 2009; Rukundo et al., 2020). All the varieties showed resistance/tolerance to sweet potato virus disease with low scores of $<2.0$ (Mekonnen et al., 2014).

There were no significant differences for interaction between genotypes and sites and over years for all traits expect for reaction to sweet potato virus disease (Table 2). Generally, the three newly released improved varieties (Dilla, Alamura and Kabode) have performed better than the check OFSP variety (Kulfo). Also, these three varieties were preferred by farmers as their 1st, 2nd and 3rd choices, respectively (Table 3 ). Highly significant effects were observed for the site effect at $(p<0.01)$, which showed the existence of significant differences among the three sites. The variety by site interaction was not significant for all traits except for virus diseases, which implies that all varieties consistently performed well across the three sites (Table 2).

\section{Farmers' varietal preferences of orange fleshed sweet potato varieties}

About 18 farmers (13 male and 5 female) were invited for variety assessment and selection, as shown in Table 3 . At harvesting, discussions were conducted with invited farmers on plant characters used by local farmers for sweet potato variety selection. Thereafter, the farmers provided their opinion on the preferred attributes and identified the traits such as vine length and thickness, above ground biomass (foliage vigor), diseases resistance/tolerance, earliness to maturity and root yield. They have mentioned the above listed attributes as farmers' preferred traits for sweet potato selection at Gedeb district of Gedeo zone.

With respect to taste-test of the sweet potato varieties, boiled roots were prepared from each variety and the attributes considered most important by farmers are flavor, taste, texture, powderiness and color of boiled roots (Table 3). Panelists using ranking scale in Table 3 to rank these characteristics. The term flavor appears to be subjective. These findings are consistent with previous works reported by Shikuku et al. (2019) and Kikulwe et al. (2011) who found that taste was an important consumption attribute with a strong influence on adoption of improved sweet potato varieties. Root texture in terms of fiber content is an important trait used by farmers in selecting sweet potato varieties. A variety root with no or low fiber content is mentioned by famers as preferred variety. Since firmness is an indication of high dry matter content, panelist have tasted a boiled roots of each tested variety for hardness/ firmness and they have selected varieties with very firm roots and noticed that this trait was more preferable by local farmers in selecting sweet potato varieties. This result agrees with findings of Shikuku et al. (2019) who explained that sweet potato varieties with good sensorial 
Table 2. Combined mean performance of orange fleshed sweetpotato varieties for yield and its components across three sites over two seasons.

\begin{tabular}{lccccc}
\hline \multirow{2}{*}{ Variety } & \multicolumn{5}{c}{ Characters } \\
\cline { 2 - 6 } & $\begin{array}{c}\text { Root yield } \\
\text { (t/ha) }\end{array}$ & $\begin{array}{c}\text { Above ground } \\
\text { biomass (t/ha) }\end{array}$ & $\begin{array}{c}\text { Harvest } \\
\text { Index (\%) }\end{array}$ & $\begin{array}{c}\text { SPVD score } \\
(\mathbf{1}-5)\end{array}$ & $\begin{array}{c}\text { Yield advantage } \\
\text { over check (\%) }\end{array}$ \\
\hline Alamura & 22.57 & 29.90 & 0.47 & 1.33 & 40.36 \\
Dilla & 23.11 & 32.62 & 0.56 & 1.67 & 43.72 \\
Vita & 15.18 & 23.38 & 0.36 & 1.33 & -5.60 \\
Kabode & 18.66 & 26.88 & 0.41 & 1.00 & 16.04 \\
NASPOT-13 & 12.10 & 20.68 & 0.35 & 1.33 & -24.75 \\
Kulfo (Check) & 16.08 & 17.15 & 0.31 & 1.67 & - \\
Mean & 18.02 & 25.83 & 0.43 & 1.38 & \\
LSD (0.05) & 2.20 & 3.03 & 0.07 & 0.30 & \\
CV (\%) & 17.37 & 19.23 & 13.96 & 20.80 & \\
& & & & & \\
Mean squares & $* *$ & $* *$ & $* *$ & $* *$ & \\
Genotype (G) & $* *$ & $* *$ & NS & $* *$ & \\
Site (S) & NS & NS & NS & $*$ & \\
GXS & & & &
\end{tabular}

Where: ${ }^{*},{ }^{* *}$ significant at $1 \%, 5 \%$ and NS = non-significant difference.

Table 3. Farmers' preference scores and ranking on sensorial attributes of the boiled roots of the six OFSP sweetpotato varieties evaluated in $2020(\mathrm{~N}=18)$.

\begin{tabular}{|c|c|c|c|c|c|c|c|}
\hline Genotypes & Flavor & Taste & Texture & $\begin{array}{c}\text { Powdery } \\
\text { (High dry matter) }\end{array}$ & $\begin{array}{c}\text { Color } \\
\text { (Boiled roots) }\end{array}$ & $\begin{array}{c}\text { Total } \\
\text { scores }\end{array}$ & Rank \\
\hline Alamura & 4.0 & 4.3 & 4.4 & 5.0 & 4.6 & 22.2 & 2 \\
\hline Dilla & 5.0 & 4.6 & 4.6 & 5.0 & 5.0 & 24.2 & 1 \\
\hline Vita & 3.3 & 3.2 & 2.6 & 3.6 & 3.6 & 16.3 & 5 \\
\hline Kabode & 3.6 & 4.0 & 4.0 & 4.3 & 4.0 & 19.9 & 3 \\
\hline Naspot-13 & 3.3 & 3.0 & 3.2 & 4.0 & 3.3 & 16.8 & 4 \\
\hline kulfo & 2.3 & 2.0 & 2.3 & 2.0 & 2.3 & 10.9 & 6 \\
\hline
\end{tabular}

Where, $\mathrm{N}=$ Number of farmers who participated in the assessment; Farmers' preference ranking using subjective scale (1-5); $1=$ bad $5=$ excellent.

Table 4. Pair-wise ranking of six orange sweetpotato varieties by farmers for different organoleptic properties in Gedeb zuria district in 2020.

\begin{tabular}{|c|c|c|c|c|c|c|c|c|}
\hline Genotypes & Alamura & Dilla & Vita & Kabode & NASPOT-13 & Kulfo & Points & Rank \\
\hline Alamura & & Dilla & Alamura & Alamura & Alamura & Alamura & 4 & 2 \\
\hline Dilla & & & Dilla & Dilla & Dilla & Dilla & 5 & 1 \\
\hline Vita & & & & Kabode & NASPOT-13 & Vita & 1 & 5 \\
\hline Kabode & & & & & Kabode & Kabode & 3 & 3 \\
\hline NASPOT-13 & & & & & & NASPOT-13 & 2 & 4 \\
\hline kulfo & & & & & & & 0 & 6 \\
\hline
\end{tabular}

attributes are best approach to solve the problems of malnutrition and facilitating food security in developing countries.
Farmers have identified their best varieties based on flesh color of boiled roots. The deep orange flesh colour of boiled roots was their best criterion and was preferred by 
most of the farmers. Considering overall ranking of the six parameters, varieties Dilla, Alamura, and Kabode were selected as the 1st, 2nd and 3rd choices in given order by farmers based on taste-tests, as shown in Tables 3 and 4 .

\section{Conclusion}

The study showed that the most desirable attributes preferred by the participant farmers were root yield, above ground biomass and resistance to virus diseases. On taste-tests, attributes such as flavor, taste, texture, and hardness of the cooked roots of the varieties were selection criteria of farmers to select their best varieties. Based on both agronomic and farmers' perception tests, three varieties namely, Dilla, Alamura and Kabode were selected and ranked as $1^{\text {st }}, 2^{\text {nd }}$ and $3^{\text {rd }}$ accordingly.

The implication from this study is that variety improvements need to pay attention to a comprehensive test of agronomic traits and the involvement of farmers for the selection and dissemination of improved technologies.

\section{CONFLICT OF INTEREST}

The authors declare that they have no conflict of interest.

\section{ACKNOWLEDGEMENTS}

The author would like to express his gratitude to the South Agricultural Research Institute (SARI) and the Ethiopian Institute of Agricultural Research (EIAR) for their financial support. The DDBIO project of CIP, funded by the Government of the United Kingdom of Great Britainand Northern Ireland acting through the Department for International Development ('DFID'), is especially acknowledged for the financial support to run the field works.

\section{REFERENCES}

Alam, M. K., Rana, Z. H., \& Islam, S. N. (2016). Comparison of the proximate composition, total carotenoids and total polyphenol content of nine orange-fleshed sweet potato varieties grown in Bangladesh. Foods, 5(3), 64.

Bowser, T. J., Ojwang, F., Sahs, R., \& Brandenberger, L. 2017. Promotion of orange fleshed sweetpotato by demonstration of acceptance and food product development. African Journal of Food Science, 11(12): 383-388.

Food and Agriculture Organization of United Nations (FAO). 2018. Strengthening sector policies for better food security and nutrition results-policy guidance note. Policy Guidance Notes. Rome: FAO, UN. Retrieved 8 May 2021 from http://www.fao.org/3/ CA2797EN/ca2797en.pdf.

Ceccarelli, S., Guimara, E. P., \& Weltzien, E. (2009). Plant breeding and farmer participation. FAO, Rome, Italy.
Ginting, E. (2013). Carotenoid extraction of orange-fleshed sweet potato and its application as natural food colorant. Journal Teknologi Dan Industri Pangan. 24, 81-88.

Gomez, K. A., \& Gomez, A. A. (1984). Statistical procedures for agricultural research. Second edition. John and Sons, New York. P. 68.

Grüneberg, W. J., Ma, D., Mwanga, R. O. M., Carey, E. E., Huamani, K., \& Diaz, F. (2015). Advances in sweet potato breeding from 1993 to 2012. In: Low, J, Nyongesa, M, Quinn, S, Parker, M. (eds.). Potato and sweet potato in Africa: transforming the value chains for food and nutrition security. UK, United Kingdom: CABI.

Gurmu, F., Shimelis, H., \& Mark, L. (2015). Diagnostic assessment of sweetpotato production in Ethiopia: constraints, post-harvest handling and farmers' preferences. Research on Crops, 16(1), 104-115.

Hawassa Agricultural Research Center (2015). Sweetpotato production and field management in Ethiopia, Production Manual. Hawassa Agricultural Research Center, Hawassa, Ethiopia.

Kikulwe, E. M., Wesseler, J., \& Falck-Zepeda, J. (2011). Attitudes, perceptions, and trust. Insights from a consumer survey regarding genetically modified banana in Uganda. Appetite, 57(2), 401-413.

Low, J., Kinyae, P., Gichuki, S., Oyunga, M. A., Hagenimana, V., \& Kabira, J. (2009). Combating vitamin A deficiency through the use of sweetpotato. International Potato Center, Lima, Peru.

Mekonnen, B., Gedebo, A., \& Gurmu, F. (2021). Genetic variability for yield and yield related traits in orange-fleshed sweet potato genotypes evaluated at Hawassa, Ethiopia. Agriculture, Forestry and Fisheries, 10(1), 28-35.

Mekonnen, S., Handaro, F., Gurmu, F., \& Urage, E. (2014). Sweetpotato Diseases Research in Ethiopia. International Journal of Agriculture and Innovation Research, 2(6), 23191473.

Ritchie, H., and Roser, M. 2017. Micronutrient deficiency. OurWorldlnData.org. Retrieved 8 May 2021 from https://ourworldindata.org/ micronutrient-deficiency.

Rodrigues, N. R., Barbosa, J. L., \& Barbosa, M. I. M. J. (2016). Determination of physico-chemical composition, nutritional facts and technological quality of organic orange and purplefleshed sweet potatoes and its flour. International Food Research Journal, 23(5), 2071-2078.

Rukundo, P., Shimelis, H., Laing, M., Mashilo, J. (2020). Genotype-by environment interaction for dual-purpose traits in sweet potato. Journal of Crop Improvement, 34(6), 800-823.

Shikuku, K. M., Okello, J. J., \& Sindi, K. (2019). Effect of farmers' multidimensional beliefs on adoption of biofortified crops: evidence from sweet potato farmers in Tanzania. The Journal of Development Studies, 55(2), 227-242

Suwarno, B., Kustiant, W. S., \& Atlin, G. N. (2002). Participatory selection on upland rice in Sumatra. Proceedings of a DFIDPlant Science Research Programme (PSP), Centre for Arid Zone Studies (CAZS)/IRRI conference, 12-15 march; 2002, IRRI, Los Bangos, Laguna, Philippines. Pp. 61-63.

Tairo, F., Kullaya, A., \& Valkonen, J. P. (2004). Incidence of viruses infecting sweet potato in Tanzania. Plant disease, 88(9), 916-920.

Tefera, T. T., Al-Niemi, S. N., Rekani, S. I., \& Gunes, A. (2013). Participatory variety selection of potato (Solanium tuberosum. L) in southern Ethiopia. Journal of Agri-Food and Applied 
Sciences, 1(1), 1-4.

Tumwegamire, S., Kapinga, R., Zhang, D., Crissman, C., \& Agili, S. (2004). Opportunities for promoting orange-fleshed sweetpotato as a mechanism for combat vitamin-A deficiency in Sub-Saharan Africa. African Crop Science Journal, 12(3), 241-252. van Jaarsveld, P. J., Faber, M., Tanumihardjo, S. A., Nestel, P., Lombard, C. J., \& Benadé, A. J. S. (2005). $\beta$-Carotene-rich orange-fleshed sweet potato improves the vitamin A status of primary school children assessed with the modified-relativedose-response test. The American Journal of Clinical Nutrition, 81(5), 1080-1087. 